\title{
PANITIA PEMUNGUTAN SUARA DALAM KESIAPAN PELAKSANAAN PEMILIHAN GUBERNUR DAN WAKIL GUBERNUR KALIMANTAN TENGAH TAHUN 2020
}

\author{
Alfrid Sentosa \\ Fakultas IImu Sosial dan IImu Politik Universitas PGRI Palangka Raya \\ (email: afrael09@gmail.com) \\ Metiana Agustina
}

Fakultas IImu Sosial dan IImu Politik Universitas PGRI Palangka Raya

\begin{abstract}
Abstrak
Penelitian ini mengangkat tentang kapasitas Panitia Pemungutan Suara (PPS) dalam kesiapan pelaksanaan pemilihan Gubernur dan Wakil Gubernur Kalimantan Tengah tahun 2020 pada masa pandemi Cocid-19 di Kelurahan Bukit Tunggal Kota Palangka Raya dengan tujuan mendeskripsikan dan mengetahui kapasitas PPS dalam kesiapan pemilhan Gubernur dan Wakil Gubernur Kalimantan Tengah Tahun 2020 pada masa pandemi covid-19

Penelitian dalam skripsi ini berjenis kualitatif dengan pendekatan deskriftif. Lokasi penelitian ini dilakukan di kelurahan Bukit Tunggal Kota Palangka Raya. Informan dalam penelitian adalah Lurah, Ketua PPS, Sekretaris PPS, Anggota PPS, dan Tokoh Masyarakat.

Hasil penelitian menunjukan bahwa kapasitas PPS dalam kesiapan pelaksanaan Pilkada Kalteng dapat dilihat dari 1) Pemahaman, yaitu PPS sangat memahami tugas mereka dalam menyelenggarakan persiapan pemilihan di Kelurahan Bukit Tunggal, serta memberikan pemahaman kepada masyarakat melalui sosialisasi. 2) Keterampilan, dilakukan dengan menjalankan tugas dengan sarana dan prasarana yang terbatas, teliti, serta memiliki ide-ide yang kreatif dengan membangun kerjasama dengan beberapa pihak dalam persiapan Pilkada Kalteng 2020. 3) Kemampuan, dilakukan dengan mampu menjalankan tugas dengan tepat waktu yang diberikan. Faktor pendukung yaitu tersedianya sarana prasarana, ada keinginan untuk berkembang, ketersediaan anggaran serta adanya kerjasama. Sedangkan faktor penghambat adalah keterbatasan sumber daya manusia, keterbatasan komunikasi, kurangnya partisipasi masyarakat akibat adanya pandemi Covid-19.
\end{abstract}

Kata kunci : Kapasitas, Panitia Pemungutan Suara, Covid-19 
Pendahuluan

$\begin{array}{crr}\text { Negara } & \text { Indonesia rnerupakan } \\ \text { negara yang } & \text { rnenganut paham }\end{array}$
demokrasi yang artinya kekuasaan atau kedaulatan berada di tangan rakyat. Hal ini tercermin dalarn pasal I ayat (2) Undang-Undang Dasar Tahun 1945 yang berbunyi "Kedaulatan berada di tangan rakyat dan dilaksanakan rnenurut Undang-Undang Dasar." Sejak kemerdekaan 17 Agustus Tanun 1945, Undang-undang Dasar Tahun 1945 dengan sangat tegas mernberikan gambaran bahwa Indonesia adalah negara demokrasi.

Menurut Beni Ahmad Saebani (2016:88-89) menjelaskan sistem pemerintahan demokrasi adalah sistem pemerintahan berdasarkan "suara mayoritas". Pemilihan penguasa oleh rakyat, baik langsung maupun melalui para wakilnya ditetapkan berdasarkan "suara mayoritas" pemilih dari rakyat. Oleh karena itu, "suara mayoritas" adalah ciri yang menonjol dari sistem pemerintahan demokrasi. Pendapat mayoritas menurut demokrasi merupakan tolak ukur hakiki yang akan dapat mengungkapkan pendapat rakyat yang sebenarnya dalam sistem pemerintahan. Kemudian Sastroatmodjo (1995:67) menyatakan negara Indonesia adalah negara yang berdasarkan prinsip kedaulatan rakyat dalam kerangka demokrasi pancasila. Di mana untuk rnewujudkan pola kehidupan sistem kedaulatan rakyat yang demokratis tersebut adalah melalui pemilihan umum. Dengan pemilihan umum tersebut, rakyat Indonesia ikut turut serta secara aktif untuk berpartisipnsi dalam memilih wakil mereka dan secara langsung atau tidak langsung mempengaruhi kebijaksanaan pemerintah karena partisipasi politik merupakun aspek penting dalam sebuah tatanan negara demokrasi sekuligus merupakan ciri khas adanya moderenisasi politik.

Pemilihan umum sebagai sarana dernokrasi telah digunakan sebagian besar negara di dunia termasuk Indonesia, yang di mana memiliki masyarakat yang heterogen. Melalui Pemilihan umum memungkinkan semua pihak bisa terakomodasi apa yang diinginkan dan cita-citakan sehingga terwujud kehidupan yang lebih baik. Pemilihan Umum Kepala Daerah (Pilkada) Tahun 2020 merupakan langkah awal terbentuknya masyarakat yang adil, makmur, sejahtera, merniliki kebebasan berekspresi dan berkehendak, dan mendapatkan akses terpenuhinya hakhak mereka sebagai warga negara. Warga negara (masyarakat) adalah komponen penentu berhasil atau tidaknya pelaksanaan pemilihan umum. Karena pada dasarnya hanya kekuatan pemilihan masyarakatlah yang bisa menentukan nasib negara dan bangsa ke depan. Setiap warga negara, apapun latar belakangnya seperti suku, agama, ras, jenis kelamin, status sosial, dan golongan, mereka memiliki hak yang sama untuk berserikat dan berkumpul, menyatakan pendapat, menyikapi secara kritis kebijakan pemerintah dan pejabat negara. Baik ini disebut hak politik yang secara luas dapat langsung diaplikasikan secara kongkrit melalui pemilihan umum.

Pilkada diselenggarakan untuk memilih pemimpin secara langsung, urnum, bebas dan rahasia oleh masyarakat Indonesia dan Pilkada dilakukan untuk memilih kepala daerah, kepala daerah tersebut antara lain Gubernur-Wakil Gubernur, Bupati-Wakil Bupati, dan Walikota-Wakil Walikota, Pilkada

\section{Jurnal Sociopolitico}


serentak menjadi tantangan bagi setiap elemen di negara ini, salah satu elemen itu adalah pemilih (warga negara) yang memiliki hak suara untuk menentukan pemenang dan masa depan setiap daerahnya dalam 5 (lima) tahun kedepan. Pilkada mendatang ini akan berbeda pada Pilkada sebelumnya karena dilaksanakan pada masa pendemic Corona Virus (Covid-19) di Indonesia bahkan di Dunia juga.

Keputusan Presiden Nomor 11 Tahun 2020 tentang Penetapan Kedaruratan Kesehatan Masyarakat Corona Virus Disease (Covid-19), Keputusan Presiden Nomor 12 Tahun 2020 tentang Penetapan Bencana Non Alam Penyebaran Corona Virus Disease (Covid-19) sebagai Bencana Nasional dan Peraturan Menteri Kesehatan Nornor 9 Tahun 2020 tentang Pedoman Pembatasan Sosial Berskala Besar Dalam Rangka Percepatan Penanganan Corona Virus Disease (Covid-19).

Berdasarkan keadaan tersebut Komisi Pemilihan Umum Republik Indonesia (KPU RI) selaku pihak penyelenggara pemilihan di Indonesia mengeluarkan Keputusan Komisi Pemilihun Umum Republik Indonesia Nomor $\quad$ : 179/PL.02Kpt/01/KPU/IH/2020 tentang Penundaan Tahapan Pemilihan Gubernur dan Wakil Gubernur, Bupati dan Wakil Bupati, dan/atau Walikota dan Wakil Walikota pada Tahun 2020 Dalam Upaya Pencegahan Penyebaran Covid19. Keputusan tersebut membuat berhentinya semua proses tahapan Pilkada untuk beberapa bulan. Berkaitan hal tersebut pemerintah Indonesia mengeluarkan Peraturan Presiden Pengganati Undang-Undang Nomor 2 Tahun 2020 tentang Pemilihan
Gubernur, Bupati dan Walikota menjadi Undang-Undang, di mana pada pasal 20 I A ayat 2 "Pemungutan suara serentak yang ditunda sebagaimana dimaksud pada ayat (I) dilaksanakan pada Bulan Desember 2020". Hal tersebut membuat proses tahapan pilkada akan dimulai kembali dengan dikeluarkannya Peraturan Komisi Pemilihan Umum Republik Indonesia Nomor 5 Tahun 2020 tentang Tahapan, Program dan Jadwal Penyelenggaraan Pemilihan Gubernur dan Wakil Gubernur, Bupati dan Wakil Bupati, dan/atau Walikota dan Wakil Walikota Tahun 2020 sehingga Pilkada dilaksanakan pada masa pandemi dengan memperhatikan protokol kesehatan. Proses tersebut juga mendapatkan dukungan dari Tim Gugus Tugas Percepatan Penanganan Covid-19 melalui surat dengan Nomor : B196/KA GUGUS/PD.O 1.02/05/2020. "Menyadari realita bahwa pandemi Covid-19 ini belum bisa dipastikan waktu berakhirnya, kami memberikan saran dan masukan kepada KPU RI sebagai penyelenggara pemilu yang mandiri, bahwa lanjutan tahapan Pilkada 2020 yang tertunda dimaksud, dapat dilanjutkan sebagaimana amanat ayat (2) Pasal 201A Perppu Nomor 2 Tahun 2020." (Doni Munardo, 2020).

Komisi Pemilihan Umum (KPU) mengeluarkan Surat Edaran Nomor 19 Tahun 2020 tentang Sistem Kerja dalam Tatanan Normal Baru di Lingkungan Komisi Pemilihan Umum, Komisi Pemilihan Umum Provinsi/ Komisi lndependen Aceh, Komisi Pemilihan Umum/Komisi Independen Pemilihan Kabupaten Kota agar dilaksanakan dalam penyelenggara Pilkada Tahun 2020. Pandemi yang terjadi merupakan suatu hal yang harus pihak

\section{Jurnal Sociopolitico}


penyelenggara antisipasi, agar Pilkada Tahun 2020 bisa terlaksana dan tetap menjunjung demokrasi di Indonesia di mana Pilkada dilaksanakan pada tanggal 9 Desember 2020.

Provinsi Kalimantan Tengah merupakan salah satu wilayah yang ikut dalarn pelaksanaan Pilkada serentak di Indonesia yang akan dilaksanakan pada 9 Desember Tahun 2020 yaitu memilih Gubemur dan Wakil Gubernur Kalimantan Tengah. Pemilihan Gubernur dan Wakil Gubernur Kalimantan Tengah tahun ini akan diikuti oleh 13 Kabupaten dan 1 Kota, 136 Kecarnatan, 139 Kelurahan dan 1.432 Desa untuk memilih Gubernur dan Wakil Gubernur Provisni Kalimantan Tengah.

Kalurahan Bukit Tunggal Kecamatan Jekan Raya Kota Palangka Raya merupakan sebuah Kelurahan yang memiliki kewajiban untuk menyelenggarakan Pemilihan Gubernur dan Wakil Gubernur Kalimantan Tengah Tahun 2020 secara serentak dengan daerah-daerah lain sesuai undang-undang demi mengsukseskan demokrasi di negeri ini. Di mana hak- hak masyarakat di sana untuk memberikan suara mereka kepada para Calon Gubernur dan Wakil Gubernur Kalimantan Tengah agar bisa menjadi pemimpin mereka untuk 5 (lima) tahun kedepannya.

Panitia Pemungutan Suara (PPS) merupakan panitia penyelenggara pemilihan di tingkat Kelurahan/Desa, di mana Panitia Pemungutan Suara (PPS) diseleksi dan dilantik oleh KPU daerah atau KPU Kota setempat. Panitia Pemungutan Suara (PPS) merupakan ujung tombak KPU dalam melakukan kegiatan-kegiatan pemilihan mulai dari sosialisasi tentang pemilihan, penetapan daftar pemilihan tetap, sampai tahap pemilihan Gubernur dan Wakil Gubernur Kalimantan Tengah Tahun 2020. Panitia Pemungutan Suara (PPS) menjadi tangan Komisi pemilihan umum (KPU) untuk menjelaskan kepada masyarakat mengenai sistem pemilihan umum di Indonesia. Panitia Pemungutan Suara (PPS) juga berkewajiban melakukan pendidikan politik pada masyarakat umum, hal ini diharapkan mampu menanggulangi terjadinya mooney politik dan mengurangi angka golput pada Pemilihan Gubernur dan Wakil Gubernur Kalimantan Tengah Tahun 2020. Pada Undang Undang Nomor 7 Tahun 2017 tentang Pemilihan Umum ayat 56 terkait tugas dari Panitia Pemungutan Suma (PPS) secara tegas dan jelas menjelaskan tentang tugas dan wewenang Panitia Pemungutan Suara (PPS) dari pasal tersebut dapat ditarik kesimpulan Panitia Pemungutan Suara (PPS) memiliki peranan yang sangat penting terhadap pelaksanaan Pemilihan Gubemur dan Wakil Gubemur Kalimantan Tengah Tahun 2020.

Panitia Pemungutan Suara (PPS) di Kelurahan Bukit Tunggal menyadari akan situasi dan kondisi saat ini dikarenakan pandemi Covid-19 akan memerlukan kesiapan yang optimal oleh Panitia Pemungutan Suara (PPS) dengan kernampuan dan keterampilan mereka, karena faktor penghambat di mana pada proses pelaksanaan nanti akan ada yang berbeda pada Pemilihan Gubernur dan Wakil Gubernur tahun-tahun sebelumnya, yaitu harus menggunakan sistem protokol kesehatan karena pandemi Covid-19 agar terciptanya rasa aman pada pelaksanaanya nanti baik untuk pihak penyelenggara maupun pihak

\section{Jurnal Sociopolitico}


masyarakat yang memberikan suara. Kemudian dalam mensosialisasikan tentang Pemilihan Gubernur dan Wakil Gubernur Kalimantan Tengah Panitia Pemungutan Suara (PPS) terkendala akibat pandemi ini, idealnya untuk mempermudah sosialisasi pihak penyelenggara bekerja sama baik penyelenggara KPUD Barito Utara, PPK dan PPS agar memberikan pendidikan tentang pemilihan pemimpin di mana hal tersebut sangat mempengaruhi kehidupan masyarakat 5 (lima) tahun ke depan. Jadi, kurang efektifnya sosialisasi membuat tingkat pengetahuan masyarakat dalam pelaksanaan Pemilihan Gubernur dan Wakil Gubernur Kalimantan Tengah akan menurun karena kurangnya sosialisasi dan pandemi yang terjadi hingga saat ini. Jadi keterampilan dari Panitia Pemungutan Suara (PPS) dalam mensosialisasikan pemilihan Gubernur dan Wakil Gubernur Kalimantan Tengah dioptimalkan dimana ia harus mampu mensosialisasikan dengan memanfaatkan segala kemampuan yang dimiliki dan memanfaatkan sarana prasarana yang sudah diberikan oleh KPU Kota.

Kendala yang serupa dalam tugas rnereka yang lain adalah dalam mengumumkan Daftar Pemilih Sementara (DPS) sampai Daftar Pernilih Tetap (DPT), karena dalam memberikan pengumuman DPS/DPT di Kelurahan akan di pasang di papan pengurnuman yang sudah ditetapkan hal tersebut akan berpotensi membuat rnasyarakat berbondong-bondong untuk melihut data mereka masing-masing, namun hal tersebut menjadi masalah karana Indonesia masih menerapkan Social Distancing (jarak sosial) sebab membuat indikasi penularan Covid-19 di masyarakat pada saat mereka berkumpul.

\section{Metode Penelitian}

Penelitian ini menggunakan metode penelitian deskriptif dengan pendekatan kualitatif. Penelitian kualitatif yaitu penelitian yang mengelola dan menggambarkan data serta infonnasi berdasarkan fakta-fakta yang tampak untuk kemudian dianalisis lebih lanjut. Metode ini tidak terbatas sampai pada pengumpulan data, tetapi meliputi juga analisis. Penyampaian data dan informasi digambarkan dalam bentuk tampilan kalimat yang lebih bermakna dan mudah dipahami.

\section{Hasil dan Pembahasan}

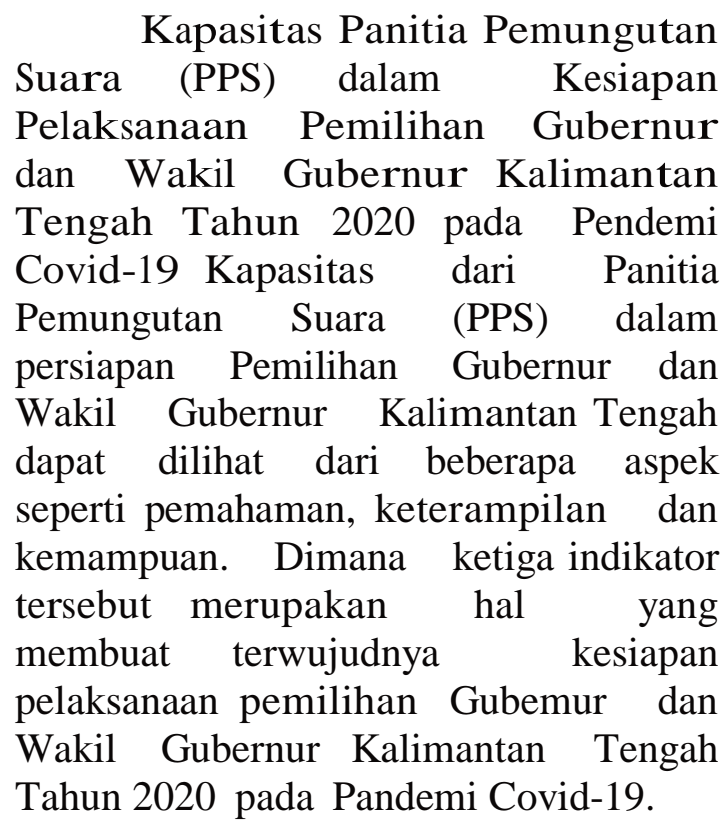

\section{Pemahaman}

Pemahaman merupakan suatu pahamanya Panitia Pemungutan Suara (PPS) atas pekerjaan dan tanggungjawab yang diterima. Dengan pemahaman Panitia Pemungutan Suara (PPS) tersebut bisa menyelesaikan tugas dan

\section{Jurnal Sociopolitico}


tanggungjawabnya dengan baik sesuai dengan arahan KPU Kota Palangka Raya.

Pemahaman

Panitia

Pemungutan Suara (PPS) dalam menjalankan tugasnya dalam persiapan khususnya tahapan awal yaitu sosialisasi sampai pemutahiran data penduduk dimana Panitia Pemungutan Suara (PPS) sudah mengetahui langkah- langkah yang mereka lakukan dengan arahan/ bimbingan teknis dari KPU Kota Palangka Raya melalui PPK Kecamatan Jekan Raya yang sudah dilaksanakan.

Salah satu faktor yang mempengaruhi pemahaman seseorang adalah informasi serta pelatihan teknis yang dilakukan oleh KPU Kota Palangka Raya dan dari individu Panitia Pemungutan Suara (PPS) untuk selalu belajar menambah pengetahuannya tidak hanya bergantung pada KPU Kota Palangka Raya. Dengan kurangnya pengetahuan memungkinkan akan terjadinya kesalahan pada tahapan persiapan baik dalam mensosialisasikan kepada warga tentang pemilihan Gubemur dan Wakil Gubernur Kalimantan Tengah ataupun pemutakhiran data pemilih di Kelurahan Bukit Tunggal.

Pelatihan teknis yang sudah dilakukan oleh KPU Kota Palangka Raya dilakukan baik secara online dan ofline guna untuk meningkatkan pemahaman akan tugas dari Panitia Pemungutan Suara (PPS), mengingat beberapa Kelurahan di Kota Palangka Raya tennasuk Kel urahan Bukit Tunggal .

Sesuai hasil penelitian di lapangan bahwa pemahaman Panitia
Pemungutan Suara (PPS) Kelurahan Bukit Tunggal Kota Palangka Raya sangat memahami akan tugas mereka dalam mempersiapkan Pemilihan Gubernur dan Wakil Gubemur Kalimantan Tengah tahun 2020 berbekal dari pelatihan teknis dari KPU Kota Palangka Raya dan pengalaman mereka pribadi yang pernah menjadi panitia Pemungutan Suara (PPS) pada tahun lalu. Jika dilihat dari hasil penelitian tersebut bahwa Kesiapan Panitia Pemungutan Suara (PPS) dalam pelaksanaan Pemilihan Gubernur dan Wakil Gubernur Kalimantan Tengah melalui pemahaman tersebut sesuai dengan pendapat Morgan dalam Soeprapto (2010:10) bahwa Pemahaman adalah seberapa jauh seseorang atau aparat tersebut memahami akan tugas mereka.

\section{Keterampilan}

Keterampilan (Skill) merupakan suatu kapasitas seseorang dalam menjalankan tugas dan tanggungjawabnya. Dalam menjalankan tugasnya Panitia Pemungutan Suara (PPS) tersebut melakukan movasi-inovasi serta ide-ide kreatif dalam melaksanakan tugas yang diberikan khususnya dalam tahapan persiapan di bagian mensosialisasikan kepada mansyarakat. Keterampilan Panitia Pemungutan Suara (PPS) sangat dituntut dalam persiapan pelaksanaan tahapan pemilihan agar tahapantahapan bias dilaksanakan dengan optimal dan bisa efektif dan efisien. Jadi memanfaatkan semua peluang yang ada merupakan suatu keterampilan Panitia Pemungutan Suara (PPS) dalam

\section{Jurnal Sociopolitico}


tahapan persiapan yaitu salah satunya mensosialisasikan pemutakhiran data penduduk pemilihan Gubernur dan Wakil Gubernur Kalimantan Tengah Tahun 2020.

Jika dilihat dari hasil penelitian di lapangan menunjukan bahwa Kapasitas Panitia Pemungutan Suara (PPS) dalam Kesiapan Pemilihan Gubernur dan Wakil Gubernur Kalimantan Tengah Tahun 2020 di Kelurahan Bukit Tunggal dilakukan dengan keterampilan yang baik. Hal tersebut dilihat dengan hadimya ideide baru khususnya dalam mensosialisasikan pemilihan pihak Panitia Pemungutan Suara (PPS) melibatkan beberapa pihak di masyarakat agar berkerjasama dalam mensosialisasikan pemilihan Gubemur dan Wakil Gubemur Kalimantan Tengah. Melalui Keterampilan tersebut senada dengan pendapat Morgan dalam Soeprapto (2010:10) bahwa keterampilan merupakan bagaimana seseorang/ aparat tersebut terampil dalam menjalankan tugasnya.

\section{Kemampuan}

Kemampuan (ability) merupakan salah satu indikator kapasitas dari seseorang. Kemampuan berasal dari kata rnampu yang artinya seseorang atau aparat tersebut bisa melaksanakan tugasnya dengan pengetahuan dan ketentuan yang berlaku Panitia Pemungutan Suara (PPS) dengan kemampuan yang mereka miliki bisa menyelesaikan tahapan persiapan Pemilihan Gunernur dan Wakil Gubernur Tahun 2020. Mempuninya Panitia pemungutan Suara (PPS) dapat dilihat dengan terlaksananya beberapa tahapan awal yang sudah mereka lakukan dari mensosialisasikan sampai tahap pemutakhiran data penduduk. Hal tersebut bisa mereka lakukan berbekal dari bimbingan teknis dari KPU Kota Palangka Raya dan pengalaman mereka serta meminta arahan dari senior/mantan Panitia Pemungutan Suara (PPS) di Kelurahan Bukit Tunggal.

Jika dilihat dari hasil penelitian di lapangan menunjukan bahwa Kapasitas Panitia Pemungutan Suara (PPS) dalam Kesiapan Pemilihan Gubemur dan Wakil Gubernur Kalimantan Tengah Tahun 2020 di Kelurahan Bukit Tunggal mampu menjalankan tugasnya. Hal tersebut bisa dilihat dengan melakukan sosialisasi kepada masyarakat tiap bulannya dan melakukan pemutakhiran data penduduk sesuai dengan ketentuan dan arahan dari KPU Kota Palangka Raya. Melalui kemampuan tersebut senada dengan pendapat Morgan dalam Soeprapt0 (2010: 10) bahwa kemampuan yaitu mampunya seseorang dalam menjalankan tugasnya.

Faktor Pendukung dan Pcnghambat Kapasitas Panitia Pemungutan Suara (PPS) Dalarn Kesiapan Pelaksanaan Pemilihan Gubernur dun Wakil Gubcrnur Kalimantan Tengah pada Pendcmi Covid-19

Kesiapan dari Panitia
Pemungutan Suara (PPS) akan
terwujudnya dengan baik karena adanya
kerjasama dari pihak penyelenggara dan
masyarakat guna mensukseskan
Pemilihan Gubemur dan Wakil Gubernur
Kalimantan Tengah Tahun 2020 pada

\section{Jurnal Sociopolitico}


masa pandemi Covid-19. Keterlibatan dari pemerintah Kelurahan, tokoh agama dan masyarakat umum sangat penting dalam persiapan pelaksanaan.

Panitia Pemungutan Suara (PPS) merupakan suatu penyelenggara Pemilihan Kepala Daerah di Tingkat Desa/Kelurahan dalam tahap awal persiapan mulai dari mensosialisasikan sampai pada proses tahapan pemutakhiran data penduduk untuk pemilihan Gubernur dan Wakil Gubernur Kalimantan Tengah tahun 2020. Untuk itu Panitia Pemungutan Suara (PPS) harus benar-benar menjalankan tugasnya selain itu Panitia Pemungutan Suara (PPS) harus didukung oleh seluruh masyarakat guna mensukseskan pemilihan kepala daerah yang berkualitas yang berasaska demokrasi

Dalam sebuah persiapan tentu ada faktor yang mendukung kesiapan dan juga ada faktor penghambat. Faktor pendukung adalah semua hal yang mendukung yang dimiliki. Sedangkan faktor penghambat adalah masalah yang dimiliki namun segera dicarikan solusinya. Di Kelurahan Bukit Tunggal juga terjadi hal yang sama yakni ada faktor pendukung dan penghambat pembangunan.

\section{Faktor Pendukung}

a. Ketersediaan Sarana Prasarana

Ketersediaan sarana prasarana merupakan modal aparat untuk mendukung jalannya suatu tugas dan tanggungjawabnya. Sarana dan prasarana yang memadai lebih memudahkan Panitia Pemungutan Suara (PPS) untuk menjalankan tugas yang sudah diberikan. Selain itu sarana prasarana juga bisa menjadi ukuran optimal atau tidaknya Panitia
Pemungutan Suara (PPS) untuk melaksanakan tugas dan fungsinya sebagai penyelenggara terutama dalam persiapan pemilihan Gubemur dan Wakil Gubemur Kalimantan Tengah 2020.

b. Ketersediaan Anggaran

Salah satu unsur penting dalam terselenggaranya suatu kegiatan adalah anggaran. Anggaran menjadi faktor penunjang segala bentuk tugas penyelenggara dalam menjalankan tugas dan fungsinya sebagai penyelenggara khususnya dalam tahapan persiapan. Besar kecilnya anggaran yang dimiliki tentu akan mempengaruhi efektivitas suatu tugas dan bisa menjadi kendala apabila anggaran yang dibutuhkan tidak sesuai dengan apa yang sudah ditetapkan.

c. Adanya Kerjasama dengan

\section{Masyarakat}

Meskipun belum maksimal namun partisipasi masyarakat dalam persiapan pemilihan di Kelurahan Bukit Tunggal merupakan salah satu faktor pendukung terlaksananya suatu tugas persiapan. Keterlibatan masyarakat ini sangat dibutuhkan agar tugas persiapan pelaksanaan Pemilihan Gubernur dan Wakil Gubernur Kalimantan Tengah Tahun 2020 yang akan dilaksanakan benarbenar murni berdasarkan kebutuhan masyarakat, sehingga masyarakat akan lebih leluasa berekspresi dan memilih pasangan calon yang mereka unggulkan.

\section{Faktor Penghambat}

a. Keterbatasan Sumber Daya Manusia (SOM)

\section{Jurnal Sociopolitico}


Dalam proses kesiapan pelaksanaan Pemilihan Gubernur dan Wakil Gubernur Kalimantan Tengah Tahun 2020 Sumber Daya Manusia merupakan faktor yang paling utama yang menentukan berhasil atau tidaknya pelaksanaan Gubernur dan Wakil Gubernur Kalimantan Tengah Tahun 2020 mendatang, Meskipun meskipun pelatihan teknis dan bimbingan teknis dari KPU Kota Palangka Raya selalu dilakukan namun seseorang tersebut tidak bisa/lambat memahaminya hal tersebut akan berpengaruh pada tugas yang mereka lakukan.

\section{b. Kurang Optimal Komunikasi}

Komunikasi yang dilakukan pada panderni Covid-19 yaitu dengan cara daring pada rapat pertama (sosialisasi PKPU 5 Tahun 2020) memang memberikan efek kurang terserapnya komunikasi dan koordinasi yang diberikan baik itu kepada KPU Kota Palangka Raya, PPK dan seluruh pihak penyelenggara maupun pengawas di Kecamatan Jekan Raya dikarenakan di Kelurahan Bukit Tunggal signal internet masih kurang stabil, namun saat ini sudah ditetapkan rapat dilakukan dengan tatap muka (offline) dengan protokol kesehatan.

c. Kurangnya Partisipasi Masyarakat

Kurangnya partisipasi masyarakat di Kelurahan Bukit Tunggal ini merupakan salah satu faktor yang menjadi penghambat pelaksanan persiapan di mana saat ini masih pandemi Covid-19 dan kebanyakan masyarakat masih acuh pada persiapan misalnya pada sosialisasi pemilihan hanya ada beberapa masyarakat yang benar-benar memperhatikan apa yang disampaikan oleh petugas, karena beberapa warga yang mereka fokuskan yaitu hanya pada hari pemungutan suara saja.

\section{Kesimpulan}

1. Kapasitas Panitia Pemungutan Suara (PPS) dalam Kesiapan Pelaksanaan Pemilihan Gubernur dan Wakil Gubernur Kalimantan Tengah Tahun 2020 pada Masa Pandemi Covid-19 dapat dilihat dari 3 indikator:

a. Kesiapan dari Panitia Pemungutan Suara (PPS) dalam menyelenggarakan Pemilihan Gubernur dan Wakil Gubernur Kalimantan Tengah Tahun 2020 dilihat dari aspek Pemahaman, di mana Panitia Pemungutan Suara (PPS) memahami tugas mereka dalam menyelenggarakan pemilihan yang berkualitas. Pemahaman tersebut juga diperlihatkan dalam cara mereka bisa mensosialisasikan pemilihan Gubernur dan Wakil Gubemur Kalimantan Tengah kepada masyarakat dan melaksanakan tahapan pemutakhiran data penduduk dengan benar sesuai pelatihan teknis dari KPU Kota Palangka Raya.

b. Kesiapan Panitia Pemungutan Suara (PPS) dari aspek Keterampilan, dilakukan dengan bisa menjalankan tugas dengan sarana dan prasarana yang terbatas dalam menjalankan tugasnya, teliti dalam pemutakhiran data penduduk serta memiliki ide-ide yang kreatif dengan membangun kerjasama dengan beberapa pihak dalam persiapan khususnya mensosialisasikan

\section{Jurnal Sociopolitico}


pemilihan Gubernur dan Wakil Gubemur Kalimantan Tengah Tahun 2020 kepada masyarakat.

c. Kesiapan Panitia Pemungutan Suara (PPS) dari aspek Kemampuan, dilakukan dengan mampu menjalankan tugas dengan tenggang waktu yang diberikan. Di mana dalam persiapan Pemilihan Gubernur dan Wakil Gubemur Kalimantan Tengah Tahun 2020 tahapan persiapan yaitu sosialisasi sampai pemutahiran data penduduk yang akan memberikan suaranya di selesaikan sesuai dengan tahapan yang ditentukan dan penuh tanggungjawab.

2. Faktor Pendukung dan Faktor Penghambat Kapasitas Panitia Pemungutan Suara (PPS) dalam Kesiapan Pelaksanaan Pemilihan Gubernur dan Wakil Gubernur Kalimantan Tengah Tahun 2020 pada Masa Pandemi Covid-19 yaitu:

a. Faktor pendukung Panitia Pemungutan Suara (PPS) yaitu ketersediaan sarana prasarana, keinginan pribadi untuk berkembang, ketersediaan anggaran dan adanya kerjasama dengan masyarakat.

b. Faktor penghambat adalah keterbatasan sumber daya manusia, komunikasi kurang optimal dan kurangnya partisipasi masyarakat karena Covid-19.

\section{Referensi}

Arifin, Anwar. 2011. Komunikasi Politik. Yogyakarta: Graha Ilmu

Beni Ahmand Saebani. 2016. Perbandingan Hukum Tata Negara. Bandung: CV Pustaka Setia

Chaplin, J.P. 2006. Kamus Lengkap Psikologi. Jakarta: PT Raja Grafindo Persada

Efriza. 2012. Political Explore Sebuah Kajian Ilmu Politik. Jakarta: Alfabeta

Irtanto. 2008. Dinamika Politik Lokal Era Otanomi Daerah: Yogyakarta: Pustaka Pelajar

Ilato. Rosman. 2017. Capacity Buliding Pemerintah Daerah Menuju Good Goverment: Upaya Mewujudkan Keseimbangan Politik, Akuntabilitas Pemerintah, dan Pertanggungjawaban Pemerintah Lokal. Malang: Ideas Publishing.

Mubarok M. Mufti. 2005. Suksesi Pilkada Jurus Memenangkan Pilkada Langsung. Surabaya: Java Pustaka Media Utama.

Miles, B Mathew dan Michael Huberman. 1992. Analisis Data Kulaitatif Buku Sumber Tentang Metode-Metode Baru. Jakarta: UIP.

Moleong, Lexy J. 2007. Metodologi Penelitian Kualitatif. Bandung: Remaja Rosdakarya.

Merphin, Panjaitan. 2013. Pendidikan Politik Indonesia. Jakarta: Ghalia Indonesia

Morgan, G. Edward, S Mikhail. 2006. Clinical Anesthesiology. New York: MC Graw Hill.

Milen, Anelli, 2004. Pegangan Dasar Pengembangan Kapasitas, Diterjemahkan secara bebas, Yogyakarta: Pondok Pustaka Yogja 
Ni'matul Huda, 2014. Hukum Pemerintahan Daerah. Bandung: Nusa Media.

Ni'matul Huda, 2009. Hukum Tata Negara Indonesia. Yogyakarta: Rajawali Press 